\title{
The campus in the twentieth century: The urban campus in Chicago from 1890 to 1965
}

After the Civil War, when socio-political reorganisation was urgently needed, American universities contributed to the process of re-establishing the internal equilibrium of power within the nation. Thus an attempt was made to reinforce the political parties and develop regions as politically discrete territorial entities that were relatively manageable. In the twentieth century the effect of this policy of local centralisation at the regional level, in conjunction with the opportunity offered by the need to develop more effective city governance, was translated into the awareness that a major contribution of academia to politics is to help re-establish the parameters of governability for the entire country. With the goal of document- ing and exploring some key relations between campus plans and city planning in Chicago, this paper illustrates a number of campus plans and planning strategies in which "the city" can be thought of as a metonym for the entire society. Nexuses between campus and city planning can be revealed from the creation of the campus of the University of Chicago in 1890 to the first half of the 1960s.

Keywords: American cities, American reformism, local-supranational conflicts, campus master plans, urban planning strategies 


\section{Introduction}

The campus in its current guise is the result of a long process of transformation. The American campus has the appearance it does today due to the university's oscillation between two prevailing positions: isolation from society and integration into society. In the twentieth century these two positions produced two distinct forms of campus: the "ivory tower" and the urban campus. Contemporary campuses result from the choices made by American universities to be either open or closed to state and national requirements, demands from industry and foundations, and ultimately the requirements of the society that exists spatially in the relation between the campus and its host city. The campus, then, as a physical and spatial entity, offers access to a set of data that enables a concatenation of reflections on the relationship between the university and society in the United States. At this point, it is useful to clarify the meaning of the word campus as used in this study, starting from a more generic definition. Generally speaking, the campus is a place that houses university buildings. Common spaces for students may confer a generic, homogeneous aspect to the campus. Furthermore, in the United States, the campus is also the place where professors develop their teaching and research activities, administrators manage the university operations and finances, and students, availing themselves of their right to study, are trained to become specialists in their chosen fields. Thus, the campus is also a very specialised place (just think of a medical or technological campus). The word campus also indicates the community that lives, works and plays within and outside of all the spaces owned by a specific university. The campus community is predominantly composed of the academic community, consisting of professors, researchers and students. In this paper the word university is used to indicate the community on campus. At present, the campus and community are mutually positioned according to two relatively different positions:

- The isolated (or semi-isolated) position; and

- The integrated position (generically internal to the urban fabric).

\section{Studies}

In the last quarter of the nineteenth century there was rapid growth in the student population, and so the campus occupied the rural space adjacent to small towns. In this period the campus defined a new attitude toward the city. Since that time, American universities have considered the University of Virginia, planned and built by Thomas Jefferson from 1817 to 1826 , a model of campus development.

The nineteenth-century campus was like a small and autonomous town that overlapped the small town nearby. Big cities were not appealing to university founders. On the contrary, in line with the concept of the "ivory tower", the metropolis provoked fear due to its potential for contamination, if not corruption (Thwings, 1883; Sharpless, 1915; Klauder \& Wise, 1929; Bush-Brown, 1958; White \& White, 1962; Tewksbury, 1965; Marcuse \& Potter, 2005). However, in the twentieth century, some campuses decided that the city was also able to offer an architectural, spatial and to a certain degree social model for future development (Dober, 1964; Bullock et al., 1968; Turner, 1984). As a consequence, more than in the past, campuses and cities entered into stronger dialogues such as the one that emerged in Chicago, which adopted the campus as an instrument of social and physical planning (Saarinen, 1960b; Parsons, 1963; Bender, 1975; Audrain, 1978; Block, 1983; Shils, 1988; Mayfield et al., 1999; Winling, 2011). This major dislocation of the university into the city enriched the campus in various ways and thus consolidated a new concept of the university in the big city: the campus of the city and in the city (Hegemann \& Peets, 1922; Bender, 1988; Kerr, 1995; Polyzoides, 1996; Muthesius, 2000; Campos Calvo-Sotelo, 2002; Kenney, 2005; Giliberti, 2007). In post-second World War America the campus is an urban developer (Blair, 1967; Rosen, 1980; Austrian \& Norton, 2002; Florida, 2005; Perry \& Wiewel, 2005). Introducing the theme of the relationship between the campus and the city also means considering the twentieth century's socioeconomic history, which in some ways forced the dialogue between the university and the city (Noble, 1987; Thomas, 1988; Altschuler, 1994; Zunz, 2002).

\section{Methodology}

This is a study of planning history whose subject is the evolution of the campus. The method utilised is historical research consisting of an analysis of certain architectural elements constituting the campus that are considered stereotypical or at least important in campus architecture and the spatial relation of the campus to the city. This study is based on primary and secondary sources: campus projects and plans, regulations related to the campus and its evolution, writings by planners involved in campus planning (e.g., reports) and existing campuses, illustrated here by photographs. This paper emphasises the transition from a rural society to an urban industrialised one and, consequently, the impact of urbanisation on campus development. The example of urbanisation referred to in this paper is centred around an analysis of campuses in the southern metropolitan area of Chicago. This paper focuses on campuses that can adequately represent the social evolution of the campus through history.

It is impossible to discuss in depth all the events that affected the campus and the city. Thus, it is necessary to select a path 
punctuated by the moments when the histories of both the campus and the city intertwined. Therefore the investigation can be limited to crucial moments in the university's transition from a prevalently rural environment to an urban one.

\section{The case of Chicago}

In the twentieth century campuses opened up to the principles of "social intelligence", which favoured a new typology of community - in contrast with the organic community worked out by German sociologist Ferdinand Tönnies - engineered, at first, by new expert figures equipped with "scientific" instruments for interpreting society that were to lead to its improvement. In particular, sociologists like Robert Park, Ernest Burgess and Albion Small offered a set of strategies that instituted a virtuous mechanism of solidarity (i.e., in Chicago, unifying the principles of social intelligence and ethics indicated by moralist reformism and philanthropic associations and promoting a marriage of academia and social ethics in the city). Furthermore, a new figure of the intellectual as conceived by John Dewey emerged. This figure arose from the complex fabric of reflections on reformism and the overall role of the intellectual in urban society. This new "service-oriented intellectual" was to be both a scholar and a planner (Shook, 2000). Furthermore, the city of Chicago in the twentieth century is a key area in urban studies and in large measure the place where urban studies emerged. In the 1920s the reformist Robert Park theorised a new approach to "social sciences" conditioned by the sociological theories developed by Georg Simmel in Germany during the same period. Moreover, the establishment of the discipline of urban studies in Chicago was influenced by John Dewey's pragmatic thinking, which saw the discipline of planning as a powerful instrument that was able to reform the city. Urban analysis developed out of the institutionalisation of these reformist ideas, which matured during the debate on the future of the big city in the United States. This paper looks at how the city of Chicago viewed the campus and vice versa.

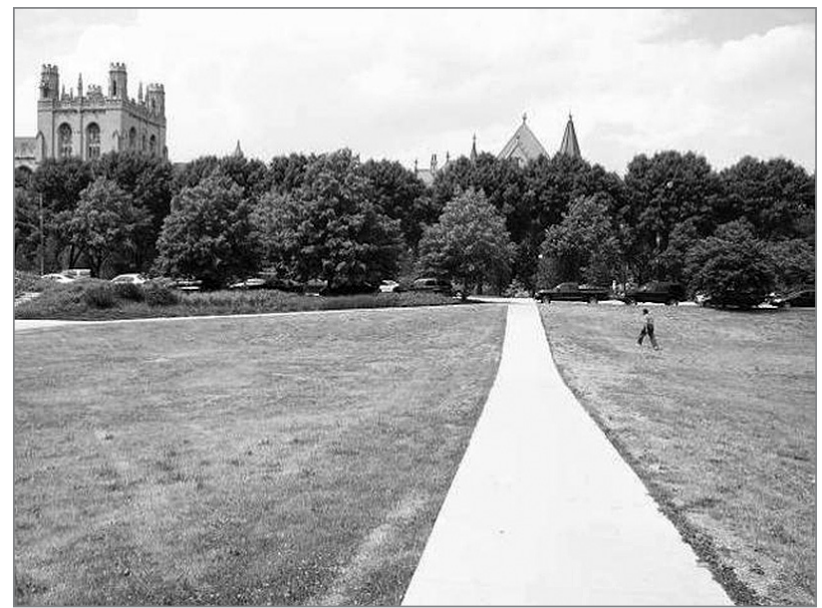

Figure 1: South view of the University of Chicago (photo: Marco Giliberti).

\section{The suburban campus}

Twentieth-century Chicago, for reasons related to its geographical position and its particular place in the history of American urbanisation, was open to changing ideas of the campus, which had been isolated in the rural setting for its first seven decades of life (Jacobs, 1961; Ciucci et al., 1973; Reps, 1981; Nugent, 1992; Corbin-Sies \& Silver, 1996; Post-Ranney, 2000; Sioli 2003; Secchi, 2005; Vettoretto, 2005; Webber, 2005). Suburban Chicago universities acted as a "laboratory" for the urban campus, particularly due to the necessity and pressing need for new buildings and spaces for the growing metropolitan student population. Thus, campus development encouraged new planning strategies (Shils, 1988). In 1890 the architect Henry Ives Cobb (1859-1931) envisioned a new campus for the University of Chicago. Cobb advocated a reform of collegiate planning that would encompass social and historical issues and that would consider campus planning a positive sign of a new era of progress and optimism (Peterson, 1976). The design for the University of Chicago offered an opportunity to rethink the suburban campus. University architecture was inspired by the famous models of Oxford and Cambridge in the United Kingdom, and the open spaces on campus were strategically planned as avenues and courts with a close relationship to the urban grid (see Figures 1 and 2; Robertson, 1916; Bush-Brown, 1958; Saarinen, 1960a; Block, 1983; Webber, 2005; Winling, 2011).

Furthermore, just like in the 1890 s, in post-war Chicago the suburban university placed campus development at the centre of its interests. In an attempt to partially redesign Chicago's depleted South Side area, southern Chicago campuses adopted campus-urban renewal strategies (South Side Planning Board, 1951). A recent émigré, the architect Walter Gropius (1883-

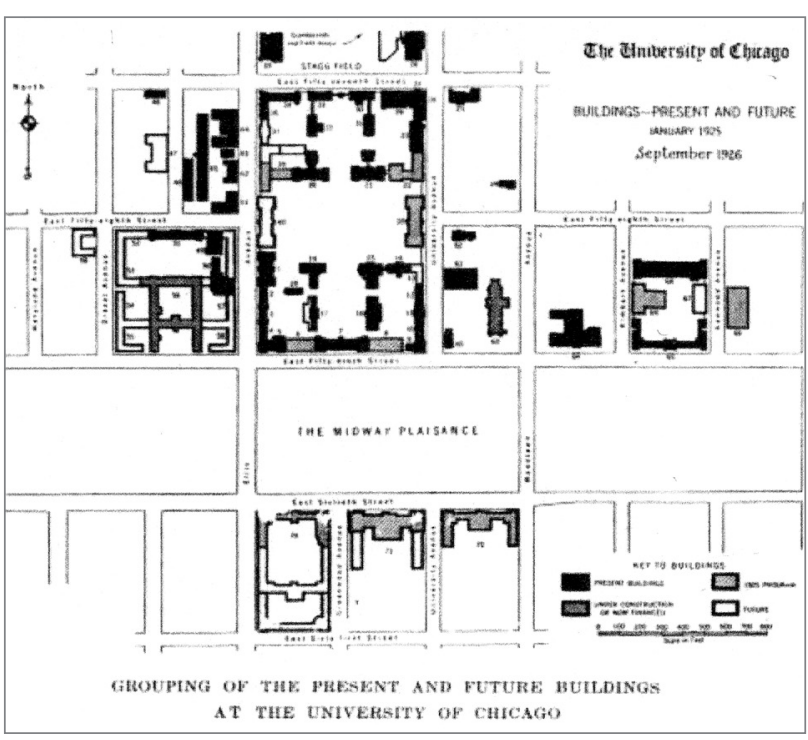

Figure 2: Map of the courtyards and buildings at the University of Chicago (source: Klauder \& Wise, 1929). 
1969) considered campus design to be an explicit response to local needs, one that could promote interactions between different levels of power such as industries, individuals and local institutions, specifically in areas in close proximity to the university (South Side Planning Board, 1952; Freeman, 1956; Pommer, 1988). Hence, in 1946, the Illinois Institute of Technology (IIT) accepted Walter Gropius' challenge.

\section{The new paradigm}

In 1940s, after more than a century of dominance, Thomas Jefferson's spatial paradigm for the university was surpassed by a new campus form. The German architect Ludwig Mies van der Rohe (1886-1969), who had lived in Chicago since 1937, had the opportunity to re-evoke in the form of the skyscraper the powerful expressionist symbolism of the cathedral of light theorised by architect Hermann Finsterlin in pre-Nazi Germany. In his plans for the campus - which alluded to the theme of the essential dominance of knowledge (the cathedral) in the metropolis - Mies deconstructed the model of the cathedral into its essential elements such as light, rhythm and geometry, recomposing all of them within the theoretical framework of the Prairie School. Then the idea of the campus as a domestic place emerged. The campus is like a garden or oasis in which student life acquires a character equal to academic activities (Isaacs, 1951). Furthermore, just like Henry Ives Cobb's University of Chicago buildings, Mies captured the implicit and pervasive mystical character of campus architecture inherited from the colonial college, a character that campus architects had unconsciously transmitted generation after generation and that now finally appeared in a quintessential form within the city, in the context generated by the designs for Illinois Institute of Technology. In the IIT campus, the Puritanical essence of the American university emerged, now finding in the campus a powerful engine of renewal and a moment of articulation in the space of the metropolis. Mies van der Rohe, for the first time in the history of the campus, arranged the university buildings freely, unbounded by geometry, in a non-hierarchical space that emancipated the pavilions from the tyranny of the lawn (Giliberti, 2008).

In the transformative 1950s and 1960s, the IIT campus evolved from "a well-landscaped oasis of fine buildings" (Isaacs, 1951) to a scientific indicator of the institutional presence within the public sphere. Furthermore, this new campus concept became a model for campus design (Bluestone, 2005). Already in the 1970s, Italian architecture historian Manfredo Tafuri, in his seminal analysis of the relation between architecture and capitalist development, underlined the fact that the transformative ideology of the Chicago Bauhaus helped promote a concept of design experimentation using practices and theories of early Chicago reformism, particularly em- phasising the relationship between scientific institutions and the city. In the specific milieu of Chicago, Walter Gropius' socio-democratic project, Mies van der Rohe's minimalism and the Chicago Planning Commission's transformative ideology informed designs for the South Side, indicating the path for a distinct form of campus (informed by the complexity of the metropolis) as a collection of significant architectural achievements and a significant institutional and cooperative model within the urban fabric (Tafuri, 1980). Chicago's Department of Urban Renewal prescribed that the campuses settled in the area (principally, the IIT and the Michael Reese Hospital) develop simultaneously with the establishment of the housing projects of Lake Meadows, Dearborn Homes, Taylor Homes, Prairie Shores, Wentworth Gardens, Ida B. Wells and Redevelopment Project Number 1 by New York Life Insurance (Isaacs, 1951). Furthermore, it should be mentioned that, specifically in 1960s, the Chicago Bauhaus and the architectural firm Skidmore, Owings \& Merrill (S. O. M.), together with the Democratic mayor of Chicago Richard J. Daley (1902-1976), offered campus plans and social planning strategies at both the metropolitan and supranational scales, as in the case of the University of Illinois at Chicago Circle.

\section{Chicago Circle}

\subsection{The metropolitan campus}

Into the milieu created by Daley must be placed this important fragment of the recent history of the metropolitan campus and the establishment: in 1965, the University of Illinois at Chicago was the largest planned university in the United States after the campus of the University of Virginia (Rosen, 1981; Allswang, 1987; Cohen \& Taylor, 2001). Daley considered the campus a specific metropolitan space and, in this way, anticipated the potential and functionality of the campus for the project of the city, making Chicago an essential place of the history of the campus and its social evolution. Thus, before the Chicago branch of the University of Illinois, Daley's vision of the urban campus was part of the patrimony of ideas of smaller towns as well as urban areas affected by the proximity of the campus.

Some other relevant facts and themes are required here in order to define the context in which this particular story took place. In the 1960s the city of Chicago witnessed the growth of giant public projects: the rebirth of downtown, construction of the McCormick Museum, expansion of O'Hare International Airport and, finally, the insertion of a branch of the University of Illinois into the metropolitan area of Chicago. Like for Thomas Jefferson's campus of the University of Virginia, the plan for the University of Illinois at Chicago Circle (as it was called then) was problematic (Barret, 1973). Its establishment was delayed by rivalry with the University of Illinois 
campus, established in the nineteenth century and located in the city of Urbana-Champaign, and the struggle for Chicago's metropolitan campus was at the centre of the public debate on the nation's future in 1960s. However, the new university campus was to overcome many obstacles, particularly including the following: the concern of small college towns regarding the introduction of the new institution in Chicago and the concern of community residents in the areas selected for the campus location (Rosen, 1980). Nonetheless, this cultural and political climate, while complicating the planning process, did not dissuade planners from their conviction about the need for a significant presence of the campus in the city. In this way, the campus became an urban product; it merged these special spatial features - consolidated in the rural and suburban ambit - with some other more markedly urban ones.

In this sense, the design for the University of Illinois at Chicago shows, for the most part, the urbanisation of the campus form and the two fundamental architectural principles that defined it: economy of space and the ability to interpret the campus as a part of the metropolitan infrastructure dense with references and meanings belonging to the Chicago architectural tradition and its most recent evolution. One could say that at that moment the campus had embarked on a successful path toward the city. The University of Illinois, once located only in its historical home in the town of Urbana-Champaign,

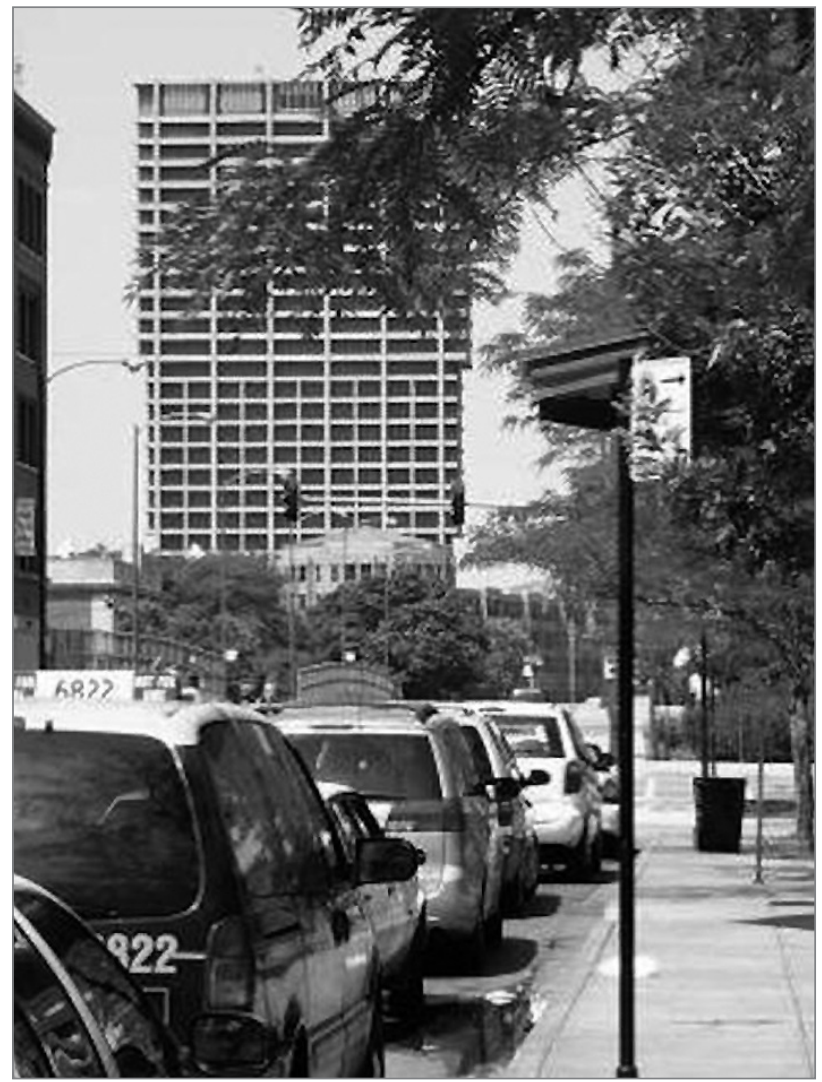

Figure 3: View of the University of Illinois at Chicago: The tower building from Harrison Street (source: Giliberti, 2005). now had a branch in Chicago. At this point the project had to clarify its pact with the city. In this negotiation, the promise to improve urban communities was the currency of exchange for the urban campus. Thus, it is also necessary to emphasise that, during the nonlinear process of implementing the project, the dialogue with local institutions and the people most susceptible to the transformation had taken place intermittently (Rosen, 1981). Furthermore, Daley ensured that the state incentives were able to activate significant programs of urban regeneration, all the while guaranteeing that the urban university would have a positive impact on growth, individuals' economic condition and the social and cultural life of the city (Giliberti, 2008).

\subsection{The S. O. M. solution}

The second Chicago Bauhaus and, specifically, S. O. M. - in collaboration with architect Walter Netsch - synthesised the entire pattern of stimuli that had emerged in more than 20 years of battles over the nature and functionality of the metropolitan campus. The S. O. M. solution was conceived to be representative of both the uniqueness and the contrasts of Chicago. The plan, in response to a request for innovation, organised the campus as a mega architectural structure: it linked the main university buildings and functions to the metropolitan transportation systems, connected the campus to the financial centre of the city and recalled the compact form of the urban village. Buildings and grounds were designed to accommodate various activities according to the principles of flexibility and economy of space. The campus' total area was divided into a variety of various spatial units. The horizontal character of these units contrasted with the vertical linearity of the office tower, re-introducing on campus the theme of verticality as an iconic element of the metropolis of Chicago. Spatial units provided space for small groups of students following the pedagogical principles of the American campus tradition. The internal web

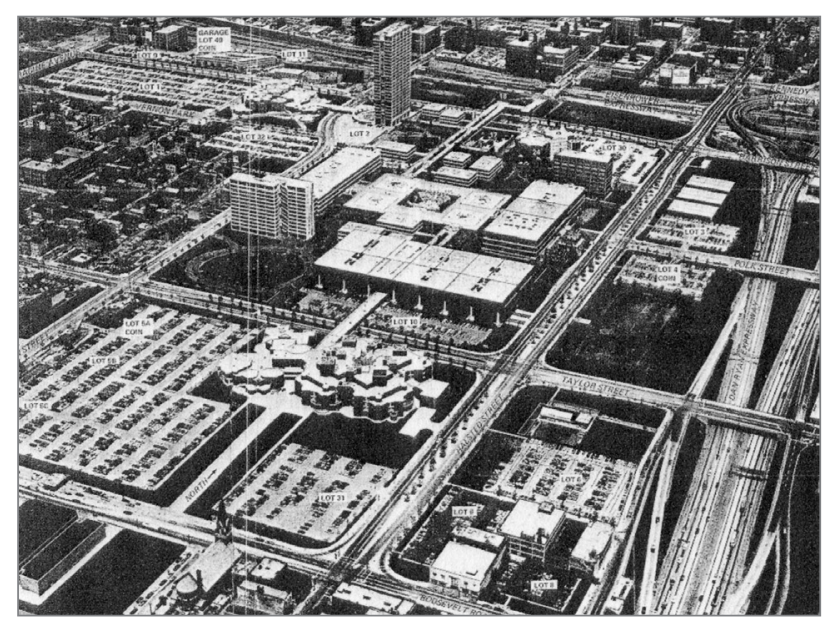

Figure 4: Image of the University of Illinois at Chicago in 1965 (source: Author's personal archive). 
of pathways on campus and its urban external matrix of roads were both designed to be generators of traffic that would shape a system of ongoing and rich relationships between the city and campus, which welcomed two thousand students in its first five years. This description of the project should note that in the first campus master plan issued between 1965 and 1969 the project focused on the design of the library, the recreation centre (the "Union") and the office tower (Saarinen, 1960b).

Skidmore, Owing and Merrill's campus designs took as their guiding principle the intent to create an articulate and complex space, a space nourished by the sophisticated icon of Chicago imagined by Daley as a model of a desirable political renewal program. Furthermore, it should be noted that in the 1960s the idea of the campus as a centrality assumed special significance in the context of the metropolitan area as a component in a system of large infrastructure nodes considered the fulcrums of renewal at supranational scale. This vision was supported by the conviction - then stubbornly opposed by influential actors from various social areas - that the city does not regenerate through activities in small parts but only within the framework of a unified design triggered by large projects oriented toward rationalising and developing the neighbouring areas (Giliberti, 2008). In this context, the campus had to sustain the revitalisation of downtown; the airport however, was to express the presence of the city in the north-western external edge of the metropolitan body, redesigning its form and meaning.

\section{The Chicago school}

To conclude this description of the urban campus in Chicago it is fruitful to return to the question of the selection of the site for the campus of the University of Illinois at Chicago. This question remained unresolved for twenty years, including the entire decade of the 1950s. At that time the necessity of a public university in Chicago had become evident as a way of responding to post-war America's socioeconomic and political problems. A focus on this topic is relevant because the choice of the area, and the project that was built on it, comes straight to the essence of the problem, displaying the ideological importance of campus planning for the metropolitan development of Chicago. Daley's ultimate objective was to place the campus in the physical centre of Chicago, preferably in close proximity to the financial centre, with the goal of making the campus

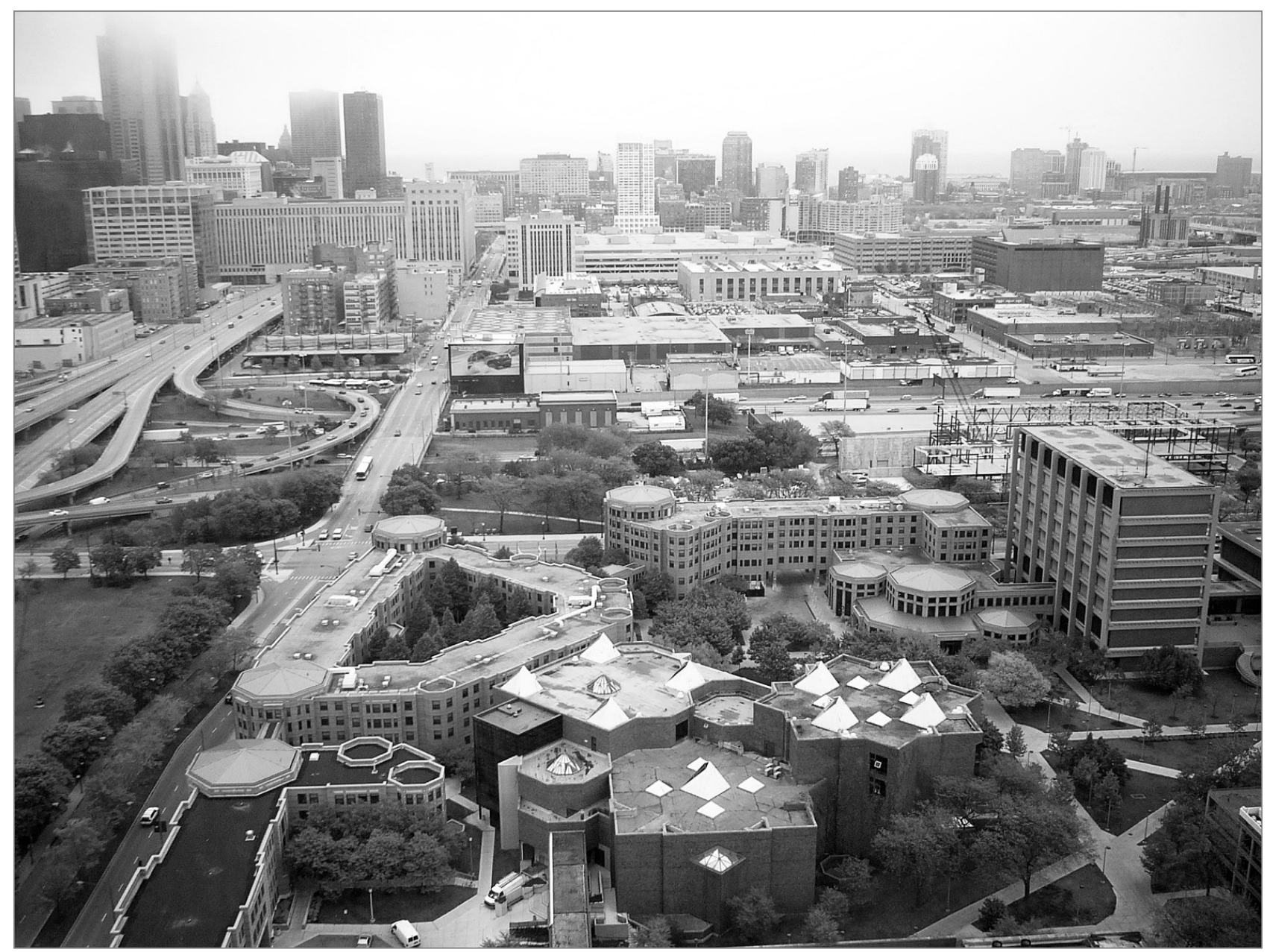

Figure 5: Bird's-eye view of the University of Illinois at Chicago (photo: Marco Giliberti). 
the engine of a virtuous process of renewal of the central urban areas. The site selected was known as Congress Circle. It faced north on Congress Avenue, the central axis planned by architect Daniel Hudson Burnham (1846-1912) that shaped the city in the early twentieth century (Condit, 1964; Peterson, 1976; Cronon, 1992; Peterson, 2003; Pacyga, 2009).

The location of the campus in the centre of twentieth-century Chicago aids in understanding Daley's urban and political intentions. The site he selected allows the campus access to the financial centre and to all the most important urban services including cultural ones (Rosen, 1981). What emerges from this selection is in fact, as the reference to David Hudson Burnham's plan recalls, the same intention to redesign the city taking into account the only scale that both Burnham and Daley perceived as functional to the scope of the metropolitan scale. This scale - in Daley's political vision - would have been manageable through designing large infrastructure and its effect on both the small and the large scale. However, the theory is not the focus of this discussion. It is rather the consideration of the fact that Daley's broad vision was strictly subordinated to the urban and metropolitan role of the campus. The campus ultimately seems to be perfectly functional as part of the socio-physical redesign of the city.

The urban campus thus appears to be a metaphor of power, or even a symbol of the political governance of the city, which is conceived of as an ensemble of important institutions. In this way, the campus emerges as a pervasive urban institution. The choice of site for the urban campus was therefore strategic: it corresponded to the will and necessity of imposing the campus as a key cultural institution of the nation. The campus was settled in the area between Harrison and Halsted streets not far from the Chicago Loop. After 1 year the university welcomed its first students. In 1982 the campus and the neighbouring medical school merged. From the physical viewpoint, a recent image of the University of Illinois Chicago shows the signs of a significant transformation completed in the 1990s. The centre of the campus, initially shielded by a mega structural roof, has now been modified into a lawn area. The office tower is still there, emerging as a solitary figure from the lower neighbourhood (see Figure 3).

Benches delimit the central part of the campus. A long pathway links the central open space to the street, where the main entrance of the campus is located. The lateral entrance of the campus is emphasised by pillars, remnants of the recent demolition of the mega structural roof originally shielding the campus. The plethora of university buildings converges toward the centre of campus. Pavilions surrounding the office tower are freely scattered on the lawn. Dorms face the street and access from the street into the campus is offered by internal porticoes.
Pathways link open spaces and dorms, but observing the office tower and the central open space of the campus reveals the complex geometric relationship studied for the original master plan (see Figure 4; Giliberti, 2007).

\section{Conclusion}

In this paper I made a priority of studying campus plans and planning strategies that offer evidence representing the university's intention to create a dialogue with the city of Chicago. These strategies were considered capable of reshaping both the physical and the cultural-ideological relationship between the campus and the city. This research relies on the fact that these campuses have modified the way university space is conceived: its form, its architectural language and particularly its relative interdependence within the space of the urban fabric. Moreover, the city of Chicago has acquired specificity in the history of the twentieth-century campus thanks to the urban campuses disseminated throughout its metropolitan area. Physical proximity to the urban fabric and urban planning are, in varying proportions, specific conditions of the majority of the campuses in Chicago: the campus should take into consideration city life and urban needs, refusing to self-segregate out of the metropolitan environment and thus from the society. In Chicago, campuses have shown a double face to the city (i.e., resistance and/or adaptability to the metropolitan pressure). In the case of adaptability, the physical and institutional presence of the city contributes to the changes in use of semi-public spaces on campus. This could be evaluated by how the proximity between the campus and urban fabric erodes the campus' spatial homogeneity, and how the architecture of the city contributes to the refinement of languages, forms and features of campus architecture. Moreover, campus architects and campus planners, among those operating in the twentieth-century urban fabric, realised an architectural synthesis of Chicago's internal conflict between propulsive forces (think of twentieth-century Chicago and its international ambitions) and conservative forces oriented toward implementing a regionalist model of development and promoting Chicago as a local power within a larger national context.

All the aspects underlined in these paragraphs converge in the present day in the contemporary definition of the urban campus: something integrated into the city, a model for urban design, an urban centrality and an agent of gentrification of the urban areas. Thus, I would like to end this paper with a note. I am aware that, in an article of this length, it is not possible to discuss in depth in all the issues related to urban campuses. However, even though it was not extensively developed in this text, I consider it of interest to mention the Chicago campus-community experience. In the first place, I did this in order to highlight the nonlinear character of this experience. 
The nonlinear character of urban campus evolution from its very beginnings emerged from my research right away. The evolution of the American university and its suburban character over the long term has traversed a path that is discontinuous. More research is needed in this direction. Therefore, at the present, the campus is promoting a dynamic set of strategies of de-privatisation implemented through investments in real estate in areas with close proximity to the university (Austrian \& Norton, 2002; Perry \& Wiewel, 2005; Weber et al., 2005).

Marco Giliberti

Auburn University, College of Architecture, Design and Construction, Landscape Architecture Program, Auburn, Alabama, USA

E-mail:mzg0014@auburn.edu

\section{Acknowledgement}

This paper was funded by a research grant from the University IUAV of Venice and it was created in cooperation with the University of lowa. The author wishes to thanks Giulio Ernesti, Marja Härmänmaa, Lucie Laurian and James A. Throgmorton for their constructive input during early versions of the manuscript. I would also like to thank Paul Kapp for recommending certain references.

\section{References}

Allswang, J. M. (1987) Bosses, machines, and urban votes. Baltimore, Johns Hopkins University Press.

Altschuler, G. (1994) Science, state and higher education in America. Journal of Social History, (fall), pp. 147-153.

Audrain, C. W. (1978) A review of planning at the University of Chicago. Chicago, University of Chicago Press.

Austrian, Z. \& Norton, J. (2002) Urban universities and real estate development. Cleveland, Lincoln Institute of Land Policy and Centre for Economic Development.

Barrett, C. W. (1973) The struggle to create a university. Publication of the University of Virginia, (49)4, pp. 494-506.

Bender, T. (1975) Toward an urban vision: Ideas and institutions in nineteenth-century America. Baltimore, Johns Hopkins University Press.

Bender, T. (1988) The university and the city: From medieval origins to the present. New York, Oxford University Press.

Blair, L. (1967) College and community: A study of interaction in Chicago. Chicago, Department of Urban Planning of the University of Illinois at Chicago Press.

Block, J. F. (1983) The uses of Gothic: Planning and building the campus of the University of Chicago. Chicago, University of Chicago Press.

Bluestone, D. (2005) More than Mies: Architecture of Chicago multifamily housing. In: Waldheim, C. \& Ray, K. R. (eds.) Chicago architecture: Histories, revisions, alternatives, pp. 82-93. Chicago, University of Chicago Press.

Bullock, N., Dickens, P. \& Steadman, P. (1968) A theoretical basis for university planning. Cambridge, Cambridge Architecture Press.

Bush-Brown, A. (1958) Image of a university: A study of architecture as an expression of education at colleges and universities in the United States between 1800 and 1900. Doctoral thesis. Princeton, NJ, Princeton University, Department of Art and Archeology.

Campos Calvo-Sotelo, P. (2002) El viaje de la utopía. Madrid, Complutense Press.

Ciucci, G., Dal Co, F., Manieri Elia, M. \& Tafuri, M. (1973) La città Americana: dalla guerra civile al New Deal. Roma, Laterza.

Cohen, A. \& Taylor, E. (2001) American pharaoh: Major Richard J. Daley his battle for Chicago and the nation. Chicago, Back Bay Books.

Condit, C. W. (1964) The Chicago School of Architecture: A history of commercial and public building in the Chicago area, 1875-1925. Chicago, University of Chicago Press.

Corbin-Sies, M. \& Silver, C. (1996) Planning the twentieth-century American city. Baltimore, Johns Hopkins University Press.

Cronon, W. (1992) Nature's metropolis: Chicago and the great west. New York, Norton \& Company.

Dober, R. P. (1964) Campus planning. New York, Reinhold.

Florida, R. (2005) The rise of the creative class. New York, Basic Books.

Freeman, L. (1956) Hospital in action: The story of the Michael Reese Medical Center. New York, Rand \& McNally.

Giliberti, M. (2007) Da ivory tower a topos della citta: il campus tra isolamento ed integrazione nel Midwest America. Doctoral thesis. Venice, University IUAV of Venice, Faculty of Architecture.

Giliberti, M. (2008) Merging campus and city planning in Chicago. Lecture presented at the Graduate Program in Urban and Regional Planning at the University of lowa, 9 September, lowa City, lowa, USA. Typescript.

Hegemann, W. \& Peets, E. (1922) The American Vitruvius: An architects' handbook of civic art. Braunschweig-Wiesbaden, Vieweg \& Sohn.

Isaac, R. R. (1951) A retrospective report on the activities of the Michael Reese Hospital planning staff: August, 1945-July, 1950. The Town Planning Review, 11(4), pp. 321-356.

Jacobs, J. (1961) The death and life of great American cities. New York Random House.

Kenney, D. R. (2005) Mission and place: Strengthening learning and community through campus design. Lanham, MD, Rowman \& Littlefield Education.

Kerr, C. (1995) The uses of the university. Cambridge, Harvard University Press.

Klauder, C. Z. \& Wise, H. C. (1929) College architecture in America. New York, Scribner's Sons.

Marcuse, P. \& Potter, C. (2005) Columbia University's Heights: An ivory tower and its communities. In: Perry, D. C. \& Wim Wiewel, W. (eds.) The university as urban developer: Case studies and analysis, pp. 45-64. New York, Sharpe.

Mayfield, L., Hellwig, M. \& Banks, B. (1999) The Chicago response to urban problems: Building university-community collaborations. American Behavioral Scientist, 42(5), pp. 863-875. DOI: 10.1177/00027642990 42005011

Muthesius, S. (2000) The postwar university: Utopianianist campus and college. New Haven, CT, Yale.

Noble, D. F. (1987) America by design: Science, technology, and the rise of corporate capitalism. New York, Oxford University Press.

Nugent, W. (1992) Demography: Chicago as a modern world city. Available at: www.encyclopedia.chicagohistory.org/pages/962.html (accessed 14 Feb. 2011). 
Pacyga, D. (2009) Chicago: A biography. Chicago, University of Chicago Press.

Parsons, K. C. (1963) A truce in war between universities and cities: A prologue to the study of city-university renewal. Journal of Higher Education, 34(1), pp. 16-28. DOI: 10.2307/1979512

Perry, D. C. \& Wiewel, W. (2005) The university as urban developer: Case study and analysis. New York, Sharpe.

Peterson, J. A. (1976) The city beautiful movement: Forgotten origins and lost meanings. Journal of Urban History, 2(4), pp. 415-434.

Peterson, J. A. (2003) The birth of city planning in the United States, 1840-1917. Baltimore, Johns Hopkins.

Polyzoides, S. (1996) On campus-making in America. Available at: http://www.mparchitects.com/articles/campusmaking.html (accessed 5 Jul. 2011)

Pommer, R. (1988) In the shadow of Mies. New York, Art Institute of Chicago.

Post-Ranney, V. (2000) Frederick Law Olmsted: Designing for democracy in the Midwest. In: William H. Tishler (ed.) Midwestern landscape architecture, pp. 41-57. Urbana, University of Illinois.

Reps, J. W. (1981) The making of urban America. Princeton, Princeton University Press.

Robertson, D. A. (1916) The University of Chicago. Chicago, University of Chicago Press.

Rosen, G. (1980) Decision-making Chicago-style: The genesis of a University of Illinois campus. Baltimore, University of Illinois Press.

Rosen, G. (1981) The siting of the University of Illinois at Chicago Circle: A struggle of the 1950s and 1960s. Chicago History,9(4), pp. 219-233.

Saarinen, E. (1960a) The re-making of south-east Chicago. The Architectural Record,4(11), pp. 131-143.

Saarinen, E. (1960b) Campus planning: The unique world of the university. Architectural Record,128(11), pp. 123-130.

Secchi, B. (2005) La città del ventesimo secolo. Rome, Laterza.

Sharpless, I. (1915) The American college. New York, Doubleday, Page \& Company.

Shils, E. (1988) The university, the city, and the world: Chicago and the University of Chicago. In: Bender, T. (ed.) The university and the city: From medieval origin to the present, pp. 210-230. Oxford, Oxford University Press.

Shook, J. (2000) Dewey's empirical theory of knowledge and reality. Nashville, TN, Vanderbilt University Press.

Sioli, M. (2003) La città industriale: Egisto Rossi nel Midwest Americano. Storia Urbana 105(1), Milan, Franco Angeli.

South Side Planning Board (1951) A redevelopment proposal for the central South Side: Chicago. Chicago.

South Side Planning Board (1952) Community appraisal study. Chicago.

Tafuri, M. (1980) Architecture and utopia: Design and capitalist development. Cambridge, MA, The MIT Press.

Tewksbury, D. G. (1965) The founding of American colleges and universities before the Civil War. New York, Archon.

Thomas, J. L. (1988) La nascita di una potenza mondiale. Gli Stati Uniti dal 1877 al 1920. Bologna, II Mulino.

Thwing, C. F. (1883) American colleges: Their students and work. New York, Putnam's Sons.
Turner, P. V. (1984) Campus: An American planning tradition. Cambridge, MA, The MIT Press.

Vettoretto, L. (2005) Chicago 1913 e oltre: concezioni rivali del city planning, tra tecnica e democrazia locale. CRU, 18(1), pp. 9-24.

Webber, H. S. (2005) The University of Chicago and its neighbors: A case study in community development. In: Perry, D. C. \& Wim Wiewel, W. (eds.) The university as urban developer. Case studies and analysis, pp. 65-79. New York, Sharpe.

Weber, R., Theodore, N. \& Hoch, C. (2005) Private choices and public obligations: The ethics of university real estate development. In: Perry, D. C. \& Wim Wiewel, W. (eds.) The university as urban developer. Case studies and analysis, pp. 285-299. New York, Sharpe.

White, M. G. \& White, L. (1962) The intellectual versus the city: From Thomas Jefferson to Frank Lloyd Wright. Cambridge, MA, Harvard University Press.

Winling, L. (2011) Students and the second ghetto: Federal legislation, urban politics, and campus planning at the University of Chicago. Journal of Planning History, 2(10), pp. 59-86. DOI: 10.1177/1538513210392002

Zunz, O. (2002) Why the American century? Chicago, University of Chicago Press. 